\section{Genetic parameters, adaptability and stability to selection of yellow passion fruit hybrids}

\author{
Alírio José da Cruz Neto ${ }^{1}$, Raul Castro Carriello Rosa², Eder \\ Jorge de Oliveira ${ }^{2}$, Sidnara Ribeiro Sampaio ${ }^{3}$, Idália Souza dos \\ Santos ${ }^{3}$, Plácido Ulisses Souza ${ }^{3}$, Adriana Rodrigues Passos ${ }^{1}$ and \\ Onildo Nunes de Jesus ${ }^{2^{*}}$
}

\begin{abstract}
The objective of this study was to evaluate the stability and adaptability, using the method of harmonic means of the relative performance of genetic values and to estimate the genetic components of variance and average via mixed models of 14 genotypes of passion fruit in three environments. Data were obtained in a random block design with three replicates and nine plants per plot. For the hybrids in the final validation phase, the estimates of heritability and genetic gains in the evaluated environments showed good prospects for selection of superior genotypes. There was a pronounced effect of genotypeenvironment interaction (GXE) for all traits investigated except fruit length, percentage of pulp, soluble solids, titratable acidity and SS/TA ratio. The most stable and adaptable hybrids in the evaluated environments were BRS Gigante Amarelo, HFOP-09, H09-09, GP09-02, GP09-03 and BRS Sol do Cerrado.
\end{abstract}

Key words: P. edulis Sims, GxE interaction, breeding, mixed models.

\section{INTRODUCTION}

Brazil is highlighted as a large producer of yellow passion fruit (Passiflora edulis Sims), and the demand for it has grown both in the markets for processed juice and natural fruits (Gonçalves et al. 2007). The latest official figures show Brazilian production of 694,539 tons in an area of 50,837 hectares (IBGE 2015), with the Northeast region standing out, accounting for $64.90 \%$ of the production. Considering the Northeast Region, Bahia State is responsible for approximately $65.96 \%$ and $42.81 \%$ of the national production (IBGE 2015). Despite such numbers, productivity in Bahia is considered low $\left(12.21 \mathrm{tha}^{-1}\right)$ compared to the culture's potential, which is estimated to be 40 to $50 \mathrm{t} \mathrm{ha}^{-1}$ (Freitas et al. 2011).

Among the factors which limit passion fruit productivity is the use of local, low-yielding varieties of unknown genetic origin. The breeding programs aim at developing more productive varieties with stronger disease resistance. For the development of new varieties, it is essential to know the variance components to better predict genetic values and to maximize selection accuracy (Farias Neto and Rezende 2001). To succeed in the selection and identification of promising genotypes, it is essential to evaluate the agronomic performance of genotypes in multiple locations. In such evaluations, the genotypes are subject to the genotype-environment interaction (GxE), which reflects differentiated behavior of the individuals in the evaluated locales. When developing varieties,
Crop Breeding and Applied Biotechnology 16: 321-329, 2016 Brazilian Society of Plant Breeding. Printed in Brazil http://dx.doi.org/10.1590/1984$70332016 v 16 n 4 a 48$ \section{(1)}


it is important for genotypes to be more stable and adapted to the adverse environmental conditions of the region for which they are being bred (Cruz et al. 2004, Silva et al. 2014).

Phenotypic stability is related to choosing the genotypes that are least affected by environmental variations, whereas adaptability is based on the identification of genotypes with predictable behaviors that can adjust to the environmental variations (Cruz et al. 2004). Currently there are several models to evaluate stability and adaptability of genotypes (Oliveira et al. 2014). The REML/BLUP method has been widely used in this type of study, as the genetic evaluation is conducted by predicting the genotypic values of selection candidates. This method provides better experimental accuracy, and it is more efficient than analysis of variance, especially in cases with unbalanced data (Resende 2004). The predicted genetic values can be used to estimate the adaptability and stability of genotypes using the harmonic mean of the relative performance of genetic values (HMRPGV), allowing estimating adaptability and stability simultaneously in a single parameter (Resende 2004). These methods have been successfully used on soybean, coffee, sugarcane and cashew crops, and their results have been found to be superior to conventional methods (Carvalho et al. 2008, Maia et al. 2009, Borges et al. 2010, Silva et al. 2015).

The objective of this study was to evaluate the stability and adaptability using the MHPRVG method and to estimate the genetic components of variance and average via mixed models (REML/BLUP) of 14 genotypes of passion fruit in three environments.

\section{MATERIAL AND METHODS}

Fourteen genotypes were evaluated - nine (GP09-02, GP09-03, H09-02, H09-07, H09-09, H09-14, and H09-30) of which from crosses between selected parents, through the Passion Fruit Plant Genetic Improvement Program of the Embrapa Cassava and Fruits (Embrapa Mandioca e Fruticultura), and five commercial hybrids (BRS Sol do Cerrado, BRS Rubi do Cerrado, BRS Gigante Amarelo, FB200, and FB300). The study was conducted in three producing centers in Bahia State: Dom Basílio (lat $13^{\circ} 45^{\prime} \mathrm{S}$, long $41^{\circ} 46^{\prime} \mathrm{W}$ and alt $200 \mathrm{~m}$ asl), Rio de Contas (lat $3^{\circ} 34^{\prime} \mathrm{S}$, long $41^{\circ} 48^{\prime} \mathrm{W}$ and alt $1300 \mathrm{~m}$ asl), and Lençóis (lat $12^{\circ} 36^{\prime} \mathrm{S}$, long $41^{\circ} 20^{\prime} \mathrm{W}$ and alt $402 \mathrm{~m}$ asl).

Each plant was spaced at $2.0 \mathrm{~m}$ in the row. The rows were spaced $2.5 \mathrm{~m}$ apart. The training system consisted of vertical espaliers with 12 wire, $2.0 \mathrm{~m}$ above the ground. The agricultural traits, the number of fruits per plot, and the productivity (TCP) - expressed in $\mathrm{t} \mathrm{ha}^{-1}$, - were evaluated. Regarding the physical and chemical characteristics of fruits, five fruits were considered per plot, and the following traits measured: fruit length (FL) in cm; fruit diameter (FD) in cm; peel thickness (PT) in mm; fruit mass (FM) in g; peel mass (PM) in g; pulp mass (PUM) in g; soluble solids (SS) in ${ }^{\circ} B$ rix, as measured with a digital refractometer; total titratable acidity (TA), expressed in $\mathrm{mg}$ citric acid per $100 \mathrm{~mL}$ juice, as determined through titration with $\mathrm{NaOH}$ at $0.1 \mathrm{~mol} \mathrm{~L}^{-1}$; percentage of pulp (PP), measured through the PUM/FM ratio in \%; and the SS/TA ratio. The measurements were performed at the peak of production, once in the areas studied, produced plants are kept in the field for a maximum of one year due to the incidence of foliar diseases.

A randomized block design was chosen, composed of 14 treatments distributed in three replicates with nine plants per plot. The following statistical model was adopted for the evaluation of genotypes with one observation per plot in three environments: $y=X_{r}+Z_{g}+W_{i}+e$, where: $\mathrm{y}$ : is the data vector, $\mathrm{r}$ : is the vector of block means (fixed), g: genotypic effects (random), i: effects of the genotype $x$ environment interaction (random), and e: is the vector of error (random). $\mathrm{X}, \mathrm{Z}$ and $\mathrm{W}$ : are the matrixes of incidence of $r, g$ and $i$, respectively. The estimates for variance components were produced based on the restricted maximum likelihood method (REML) where the following components of variance and genetic parameters were estimated: $\sigma_{g}^{2}$ : genotypic variance. $\sigma_{\text {int }}^{2}$ : variance of the genotype x environment interaction. $\sigma_{r}^{2}$ : residual variance. $\sigma_{p}^{2}$ : individual phenotypic variance. $h_{g}^{2}$ : broad-sense heritability of individual plots; that is, of the total genotypic effects. $h_{m g}^{2}$ : genotype average heritability, assuming full survival. $A_{\text {cgen }}$ : accuracy of the genotype selection, assuming full survival. $c_{\text {int }}^{2}$ : coefficient of determination of the genotype $x$ environment interaction effects. $r_{\text {gloc }}$ : genotypic correlation between performances in the various environments. $C V_{g i}$ : genotypic coefficient variation in $\%$. $C V_{r}$ : residual coefficient variation in \%. $\mu$ : general experiment average. The genetic values were predicted through the best linear unbiased prediction (BLUP) method. The interaction-free $(\mu+\mathrm{g})$ genotypic values of each hybrid were obtained by adding each genotypic effect $(\mathrm{g})$ to the general experiment average $(\mu)$. The genetic gain corresponded to the average of genetic effect vectors that were predicted for the selected hybrids. The sum of the general average $(\mu)$ 
and the genetic gain resulted in the new average for the improved population. The estimates of genetic parameters and the adaptability and stability (HMRPGV - harmonic mean of the relative performance of genetic values) were obtained by mixed models (REML/BLUP), through the use of the SELEGEN genetic and statistical software, model 54 (Resende 2007).

\section{RESULTS AND DISCUSSION}

The estimation of genetic parameters is important to guide genetic breeding programs, as these predict genetic values and maximize selection, thus helping the selective process for recommendation of new commercial materials (Farias Neto and Rezende 2001, Maia et al. 2009). The estimates for variance components are shown in Table 1. In general, the contribution of the genotypic variance $\left(\sigma_{g}^{2}\right)$ for the phenotypic variance $\left(\sigma_{p}^{2}\right)$ was 11.44 to $35.05 \%$ for productivity traits (TCP) and peel mass (PM), respectively. The variances of residual effects $\left(\sigma_{r}^{2}\right)$ were the ones that most contributed to $\sigma_{p^{\prime}}^{2}$, with variations from 45.71 to $75.90 \%$ for fruit length and soluble solids, respectively. Since the evaluated traits are quantitative and therefore highly influenced by the environment, residual variance tends to be high (Atroch et al. 2013). Studies conducted with eucalyptus (Rosado et al. 2012) and clones of guarana plants (Atroch et al. 2013), were also found to have higher contributions from the residual variance than the phenotypic variance. Studying passion fruit, Santos et al. (2015) reported higher values of environmental variance for fruit mass. In yellow passion fruit plant populations, Viana et al. (2003) reported contributions of $64 \%$ and $48 \%$ (fruit length and diameter) for the environmental variance.

The variance from the GxE interaction $\left(\sigma_{\text {int }}^{2}\right)$ had the smallest contribution to $\sigma_{p^{\prime}}^{2}$ ranging from 10.00 to $23.12 \%$ for traits titratable acidity and total cumulative productivity, respectively (Table 1). A low magnitude of GxE interaction $\left(\sigma_{\text {int }}^{2}\right)$ indicates uniformity in the performance of genotypes according to environmental variations and thereby greater adaptability and genetic stability of individuals (Maia et al. 2009, Rosado et al. 2012). The $\sigma_{\text {int }}^{2}$ is associated with the coefficient determination of the effects of GxE interaction $\left(c_{\text {int }}^{2}\right)$, since it represents the percentage of $\sigma_{\text {int }}^{2}$ present in $\sigma_{p}^{2}$ and therefore exhibits the same value (Table 1). Due to the lower $\sigma_{\text {int }}^{2} / c_{\text {int }}^{2}$, the genotypic correlation between performances in the various environments $\left(r_{\text {gloc }}\right)$ showed values of 0.51 to 0.74 for most characteristics, except for total cumulative productivity and pulp mass with 0.33 and 0.49 , respectively (Table 1). However, the values are not yet high enough for all the characteristics, which reinforces the need to further study the adaptability and stability.

The residual coefficients' variation $\left(C V_{r}\right)$ ranged from $4.73 \%$ to $24.88 \%$ for FD and TCP, respectively (Table 1$)$. In other fruit plants, such as the cashew tree, values of $C V_{r}$ close to $34 \%$ were reported (Maia et al. 2009). Besides that, in passion fruit plants, Oliveira et al. (2008) reported $C V_{r}$ ranging from $4.76 \%$ for fruit length to $20.48 \%$ for number of

Table 1. Estimates of variance components (REML) in 14 yellow passion fruit hybrids evaluated in three locations in the State of Bahia for traits: total cumulative productivity (TCP), fruit mass (FM), fruit length (FL), fruit diameter (FD), peel thickness (PT), peel mass (PM), pulp mass (PUM), percentage of pulp (PP), soluble solids (SS), titratable acidity (TA), and SS/TA ratio

\section{Parameters}

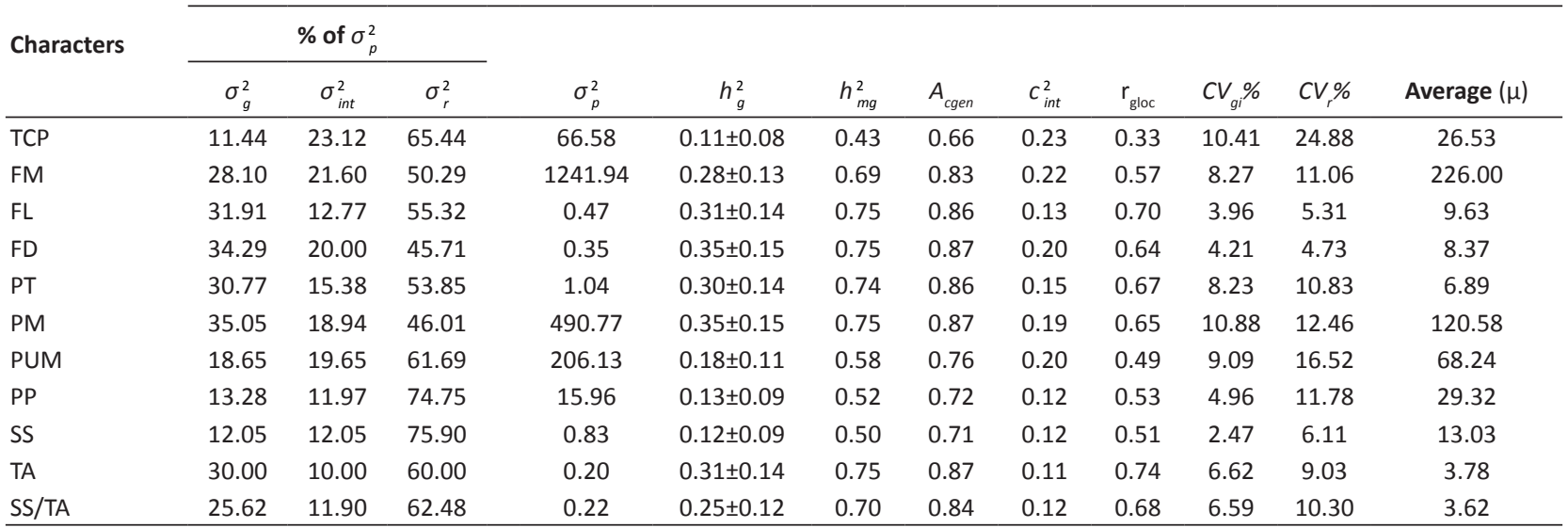

$\sigma_{g}^{2}$ : genotypic variance. $\sigma_{\text {int }}^{2}$ variance of the genotype x environment interaction. $\sigma_{r}^{2}$ : residual variance. $\sigma_{p}^{2}$ : individual phenotypic variance. $h_{g}^{2}$ : broad-sense heritability of individual plots; that is, of the total genotypic effects. $h_{m g}^{2}$ : genotype average heritability, assuming full survival. $A_{\text {cgen }}$ : accuracy of the genotype selection, assuming full survival. $c_{\text {int }}^{2}$ : coefficient of determination of the genotype $x$ environment interaction effects. $r_{\text {gloc }}$ : genotypic correlation between performances in the various environments. $C V_{g i}$ : genotypic coefficient variation in $\% \mathrm{CV}_{r}$ : residual coefficient variation in \%. $\mu$ : General experiment average. 
fruits. Although the adoption of a higher number of repetitions can contribute to environmental control and reduced residual coefficient variation $\left(C V_{r}\right)$, the values are considered low for quantitative a characteristic, which indicates good experimental quality (Rosado et al. 2012).

The genotypic coefficient of variation $\left(C V_{g i}\right)$, ranged from $2.47 \%$ for the variable soluble solids (SS) to $10.88 \%$ of peel mass (PM) (Table 1) that indicates there was genetic variability among the analyzed hybrids. In another study of passion fruit, Viana et al. (2003) found variations of 0.00 to $52.78 \%$ for the $C V_{g i}$ for the characteristics percentage of pulp and number of fruits. The values of $C V_{r}$ and $C V_{g i}$ influence the accuracy statistics (Resende and Duarte 2007). The accuracy of the genotype selection $\left(A_{c g e n}\right)$, which is the square root of $h_{m g^{\prime}}^{2}$ reflects the correlation between the true genotypic value and the estimated values (Resende et al. 2002, Cargnelutti-Filho and Storck 2009) and shows a good experimental quality and security in the selection of superior genotypes (Carvalho et al. 2016). High accuracy values (0.71 to 0.87) were observed for most evaluated traits, except for total cumulative productivity (0.66), which presented moderate accuracy in accordance with the classification proposed by Resende and Duarte (2007) (Table 1). Furthermore, high values of this parameter indicate the existence of genetic variance among the genotypes (Maia et al. 2009).

Broad-sense heritability of individual plots $\left(h_{g}^{2}\right)$ expresses the genetic variation between genotypes, and it also supports the definition of the most suitable improvement methods to be used in breeding programs (Resende 2002). The values of $h_{g}^{2}$ ranged from 0.11 for total cumulative productivity to 0.35 for fruit diameter and peel mass, and were associated with high values of deviations (Table 1), which indicates individual selection may not be effective. Santos et al. (2015), evaluated interspecific progenies of passion fruit, and found similar results to this study, except for the traits PUM and SS, which were found to be 0.61 and 0.62 , respectively, indicating the possibility of successful individual selection for those two traits. The estimated average heritability $\left(h_{m g}^{2}\right)$ values were higher, varying from 0.43 to 0.75 (Table 1). The traits that were found to have the highest $h_{m g}^{2}$ values (0.69 to 0.75 ) were fruit mass, peel thickness, fruit length, fruit diameter, titratable acidity, and peel mass. With the exception of fruit mass, which obtained a similar value of 0.68 , the remaining traits were higher than those observed by Viana et al. (2003) evaluating yellow passion fruit plant populations in two distinct environments. Oliveira et al. (2008) evaluating in half-sibling progenies of yellow passion fruit observed values lower of $h_{m g}^{2}$ of $0.28,0.30,0.51$, and 0.57 for variables percentage of pulp, fruit diameter, fruit length, and fruit mass, respectively. Moraes et al. (2005) found a larger value of $h_{m g}^{2}$ for fruit length and soluble solids, and a lower for fruit mass and fruit diameter, while evaluating an $\mathrm{F}_{1}$ population of yellow passion fruit. High $h_{m g}^{2}$ estimates demonstrate good genetic control of a trait, and high potential for selecting superior genotypes. Thus, most of the observed variation in the yellow passion fruit plants was genetic, allowing high selective accuracy rates for most agricultural traits. However, the traits total cumulative productivity, soluble solids, percentage of pulp, and pulp mass were found to have moderate values of $0.43,0.50,0.52$, and 0.58 , respectively (Table 1 ). These values reflect the low genetic variance ( 11.44 to $18.65 \%$ of $\sigma_{p}^{2}$ ) and the high residual variance of 61.69 to $75.90 \%$ of $\sigma_{p}^{2}$ (Table 1 ). Thus, they tended to have low $h_{g^{\prime}}^{2} h_{m g}^{2}$ and $A_{c g e n}$ and therefore smaller genetic gains for those traits (Table 1 ).

The differences observed in the heritability estimate values is acceptable, as that is an estimate that can fluctuate due to several factors, among them the genetic structure of the evaluated population (Santos et al. 2015), the changes in genetic and phenotypic parameters linked to the studied trait, the estimation method, the diversity of the population, the evaluated environment, the sample size, and the experimental accuracy (Hallauer and Miranda Filho 1988). It is important to point out that the inferences from the genetic parameters that are defined in this study originate from the evaluation of genotypes in three distinct environments. This makes the estimates more reliable (Resende and Dias 2000) and maximizes the genetic gains in the presence of the genotype $x$ environment interaction (Costa et al. 2002). The studied population comprised genotypes in the final evaluation stage, from which genetic material was selected. However, even under these conditions, the genotypes still exhibited genetic variability that can be used for selection, through crosses aiming at increasing the frequency of favorable alleles.

Tables 2 and 3 show the genotypic effects $(g)$, interaction-free genotypic values $(\mu+g)$, genetic gains, and new predicted average for the 14 hybrids evaluated. The genotypic values are the true values to be predicted and the new average values are predictions of the performance of selected hybrids (Borges et al. 2010). Some negative genotypic effects (- g) were identified in some hybrids and for most evaluated traits. Those values indicate the hybrids are below the general average $(\mu)$ and that they would be discarded in the selective process, because they may not carry desirable genetic complements in their genomes. It is possible to infer that such genotypes will interact significantly with their 
environment, which is not desirable for development of new varieties (Maia et al. 2009). For the total cumulative productivity trait (TCP), $57 \%$ of the hybrids were found to be superior to the general average $(\mu)$, which was $26.53 \mathrm{t} \mathrm{ha}^{-1}$ (Table 2). Genotypes BRS Gigante Amarelo, H09-09, GP09-03, BRS Rubi do Cerrado, and BRS Sol do Cerrado were, in that order, the five best for that trait. The new average for this trait varied from 28.92 to $28.17 \mathrm{t} \mathrm{ha}^{-1}$ and gains ranged from 2.39 to $1.65 \mathrm{t} \mathrm{ha}^{-1}$ (Table 2). Those gains are promising for the passion fruit productive sector, as the observed values for total cumulative productivity exceed the national average and the one for the State of Bahia, which are $13.66 \mathrm{t} \mathrm{ha}^{-1}$ and $12.21 \mathrm{t} \mathrm{ha}^{-1}$, respectively (IBGE 2015).

Fruit mass (FM) is an important characteristic for the in natura consumption market, once larger fruits are preferred by consumers (Negreiros et al. 2007). Therefore, taking this information into consideration, the five best genotypes were BRS Gigante Amarelo, H09-30, HFOP-09, GP09-02, and H09-09, with gains from 38.97 to 14.60 g, respectively (Table

Table 2. Estimates of the genotypic effect; average predicted value in the environments, gain and new average in 14 yellow passion fruit hybrids evaluated in three locations in the State of Bahia for physical traits of fruits: total cumulative productivity (TCP), fruit mass (FM), fruit length (FL), fruit diameter (FD), peel thickness (PT), peel mass (PM), pulp mass (PUM), and percentage of pulp (PP)

\begin{tabular}{|c|c|c|c|c|c|c|c|c|c|c|c|c|c|c|c|c|}
\hline Genotypes & \multicolumn{4}{|c|}{$\begin{array}{l}\text { Total cumulative productivity } \\
\text { (TCP) }\end{array}$} & \multicolumn{4}{|c|}{$\begin{array}{l}\text { Fruit mass } \\
\text { (FM) }\end{array}$} & \multicolumn{4}{|c|}{$\begin{array}{l}\text { Fruit length } \\
\text { (FL) }\end{array}$} & \multicolumn{4}{|c|}{$\begin{array}{l}\text { Fruit diameter } \\
\text { (FD) }\end{array}$} \\
\hline HFOP-08 & -0.68 & 25.85 & 0.94 & 27.47 & -2.97 & 223.04 & 7.44 & 233.44 & -0.13 & 9.50 & 0.19 & 9.82 & -0.01 & 8.35 & 0.16 & 8.53 \\
\hline HFOP-09 & -1.31 & 25.22 & 0.74 & 27.26 & 13.81 & 239.82 & $\underline{23.06}$ & 249.06 & 0.15 & 9.78 & $\underline{0.36}$ & 9.99 & 0.02 & $\begin{array}{l}8 . \\
39\end{array}$ & $\underline{0.29}$ & 8.66 \\
\hline H09-09 & 2.12 & 28.65 & $\underline{2.26}$ & 28.78 & 1.71 & 227.72 & $\underline{14.60}$ & 240.61 & 0.22 & 9.85 & $\underline{0.41}$ & 10.04 & 0.01 & 8.38 & 0.25 & 8.62 \\
\hline BRS-SC & 0.98 & 27.51 & 1.65 & 28.17 & -2.13 & 223.87 & 8.74 & 234.74 & -0.32 & 9.31 & 0.10 & 9.73 & 0.13 & 8.50 & $\underline{0.36}$ & 8.73 \\
\hline H09-14 & 0.76 & 27.29 & 1.40 & 27.93 & 0.20 & 226.21 & 12.20 & 238.21 & -0.23 & 9.40 & 0.15 & 9.78 & 0.14 & 8.51 & $\underline{0.44}$ & 8.81 \\
\hline FB200 & -2.44 & 24.09 & 0.29 & 26.82 & -24.65 & 201.36 & 0.00 & 226.00 & -0.38 & 9.25 & 0.03 & 9.66 & -0.50 & 7.87 & 0.00 & 8.37 \\
\hline BRS-GA & 2.39 & 28.92 & $\underline{2.39}$ & 28.92 & 38.97 & 264.97 & $\underline{38.97}$ & 264.97 & 0.62 & 10.25 & $\underline{0.62}$ & 10.25 & 0.55 & 8.91 & $\underline{0.59}$ & 8.95 \\
\hline GP09-02 & 0.81 & 27.34 & 1.51 & 28.03 & 2.12 & 228.12 & $\underline{17.83}$ & 243.83 & 0.32 & 9.95 & $\underline{0.47}$ & 10.10 & -0.01 & 8.36 & 0.18 & 8.55 \\
\hline \multirow[t]{2}{*}{ Average $(\mu)$} & & & & 26.53 & & & & 226.00 & & & & 9.63 & & & & 8.37 \\
\hline & \multicolumn{4}{|c|}{ Peel thickness (PT) } & \multicolumn{4}{|c|}{ Peel mass (PM) } & \multicolumn{4}{|c|}{ Pulp mass (PUM) } & \multicolumn{4}{|c|}{ Percentage of pulp (PP) } \\
\hline Genotypes & g & $\mu+g$ & Gain & $\begin{array}{c}\text { New } \\
\text { Average }\end{array}$ & g & $\mu+g$ & Gain & $\begin{array}{c}\text { New } \\
\text { Average }\end{array}$ & g & $+g$ & Gain & $\begin{array}{c}\text { New } \\
\text { Average }\end{array}$ & g & $+g$ & Gain & $\begin{array}{c}\text { New } \\
\text { Average }\end{array}$ \\
\hline GP09-03 & -0.18 & 6.71 & 0.34 & 7.22 & 1.06 & 121.64 & 0.01 & 129.40 & -0.62 & 67.62 & 3.03 & 71.28 & -0.22 & 29.10 & 0.55 & 29.87 \\
\hline HFOP-08 & 0.36 & 7.24 & $\underline{0.57}$ & 7.45 & 2.61 & 123.19 & 10.11 & 130.69 & -4.27 & 63.97 & 1.04 & 69.28 & -1.04 & 28.28 & 0.20 & 29.52 \\
\hline HFOP-09 & 0.44 & 7.32 & $\underline{0.64}$ & 7.52 & 7.38 & 127.97 & $\underline{15.43}$ & 136.02 & 4.48 & 72.72 & $\underline{7.93}$ & 76.17 & 0.41 & 29.73 & 0.74 & 30.06 \\
\hline H09-30 & 1.00 & 7.88 & $\underline{1.00}$ & 7.88 & 15.68 & 136.26 & $\underline{19.46}$ & 140.04 & 0.68 & 68.92 & 3.55 & 71.80 & -0.81 & 28.51 & 0.43 & 29.75 \\
\hline FB300 & 0.09 & 6.98 & 0.41 & 7.30 & -8.37 & 112.22 & $\underline{3.95}$ & 124.54 & 1.38 & 69.62 & 4.03 & 72.28 & 0.80 & 30.12 & $\underline{0.94}$ & 30.25 \\
\hline H09-09 & -0.35 & 6.54 & 0.21 & 7.09 & -2.09 & 118.50 & 7.45 & 128.04 & 2.26 & 70.51 & $\underline{5.29}$ & 73.53 & 0.76 & 30.08 & $\underline{0.87}$ & 30.19 \\
\hline H09-02 & -0.73 & 6.15 & 0.00 & 6.89 & -11.44 & 109.15 & 2.67 & 123.26 & -2.27 & 65.98 & 2.44 & 70.69 & 0.37 & 29.69 & 0.70 & 30.01 \\
\hline GP09-02 & -0.42 & 6.46 & 0.11 & 6.99 & -3.78 & 116.81 & 6.20 & 126.79 & 3.03 & 71.28 & $\underline{6.29}$ & 74.54 & 0.78 & 30.10 & $\underline{0.90}$ & 30.22 \\
\hline Average $(\mu)$ & & & & 6.89 & & & & 120.58 & & & & 68.24 & & & & 29.32 \\
\hline
\end{tabular}

g: genotypic effect; $\mu+\mathrm{g}$, average predicted value in the environments; $\mu$, general experiment average. BRS Sol do Cerrado (BRS-SC); BRS Gigante Amarelo (BRS-GA). The five best hybrids for each evaluated trait are underlined. 
2). In this case, the new average prediction for the above genotypes regarding fruit mass are 264.97 to $240.61 \mathrm{~g}$ and productivity of 28.92 to $28.78 \mathrm{t} \mathrm{ha}^{-1}$ (Table 2), therefore with estimates of higher values in comparison to the ones obtained for the UENF Rio Dourado cultivar (Pio Viana et al. 2016).

The characteristics for fruits length and diameter are also appreciated by consumers, because this means greater number of seeds and thus higher percentage of pulp (Negreiros et al. 2007). However, it is desirable for these traits to be accompanied by smaller peel thickness at the moment of selecting new varieties (Neves et al. 2013). Among the five best for fruit length and diameter, hybrids HFOP-09 and BRS Gigante Amarelo stood out, with respective gains of 0.36 and 0.62 for fruit length, and 0.29 and 0.59 for fruit diameter (Table 2). There were respective gains of 0.51 to 1.0 , and 11.61 to 23.24 for the traits peel thickness and peel mass, with special mention to genotypes H09-30, HFOP-09, H0914, and BRS Rubi do Cerrado, which were best for those traits. BRS Gigante Amarelo stood out with the highest gain for peel mass, with 23.24 (Table 2). High peel mass and peel thickness values are undesirable, as they do not contribute to percentage of pulp, especially in fruits for industrial processing (Medeiros et al. 2009).

Seed-free pulp mass and percentage of pulp are attractive traits to the juice industry, which establishes a minimum acceptable yield of 33\% (Nascimento et al. 1999). For the PUM trait, the hybrids found to have the highest genetic gains were BRS Gigante Amarelo, HFOP-09, GP09-02, H09-09, and BRS Sol do Cerrado, with results ranging from 11.34 to 4.57 (Table 2). Those materials exceeded the general experimental average (68.24 g), ranging from 72.81 to 79.61 for the new predicted average. Regarding percentage of pulp, the best genotypes were FB200, BRS Sol do Cerrado, FB300, GP09-02, and H09-09, varying from 30.33 to 30.19 (Table 2). Genotypes H09-09, BRS Sol do Cerrado, and GP09-02 also showed large gains for pulp mass and percentage of pulp.

For the soluble solids, the genotypic average was similar to the new predicted average. This is possibly related to the lower gains, from 0.0 to 0.39 (Table 3). Still, genotypes H09-30, FB200, H09-07, BRS Sol do Cerrado and HFOP-09 had a certain level gain for this trait (Table 3). Fruit pulp acidity is desirable for the agroindustry since higher acidity avoids microbiological deterioration, allowing better product conservation as well as reducing the need for artificial acid addition (Freitas et al. 2011). For titratable acidity, the genotypes with best genetic gain were H09-30, BRS Gigante Amarelo, HFOP-09, HFOP-08, and H09-14 (Table 3). The values observed for TA were above the limit established by the Ministry of Agriculture, of 2.5\% (Brasil 2003). From the SS/TA ratio, it is possible to evaluate fruit flavors, since it expresses the ratio between sugars and acids (Freitas et al. 2011). The five best hybrids were H09-07, BRS Rubi do Cerrado, FB200,

Table 3. Estimates of the genotypic effect, average predicted value in the environments, gain and new average in 14 yellow passion fruit hybrids evaluated in three locations in the State of Bahia for chemical traits of fruits: soluble solids (SS), titratable acidity (TA), SS/TA ratio

\begin{tabular}{|c|c|c|c|c|c|c|c|c|c|c|c|c|}
\hline \multirow[b]{2}{*}{ Genotypes } & \multicolumn{4}{|c|}{ Soluble solids (SS) } & \multicolumn{4}{|c|}{ Titratable acidity (TA) } & \multicolumn{4}{|c|}{ SS/TA } \\
\hline & g & $\mu+g$ & Gain & $\begin{array}{c}\text { New } \\
\text { Average }\end{array}$ & $\mathbf{g}$ & $\mu+g$ & Gain & $\begin{array}{c}\text { New } \\
\text { Average }\end{array}$ & g & $\mu+g$ & Gain & $\begin{array}{c}\text { New } \\
\text { Average }\end{array}$ \\
\hline GP09-03 & 0.03 & 13.06 & 0.16 & 13.18 & 0.04 & 3.82 & 0.19 & 3.96 & -0.05 & 3.57 & 0.12 & 3.74 \\
\hline HFOP-09 & 0.08 & 13.10 & $\underline{0.23}$ & 13.26 & 0.18 & 3.96 & $\underline{0.30}$ & 4.08 & -0.14 & 3.48 & 0.09 & 3.71 \\
\hline H09-30 & 0.39 & 13.41 & $\underline{0.39}$ & 13.41 & 0.43 & 4.20 & $\underline{0.43}$ & 4.20 & -0.22 & 3.40 & 0.03 & 3.65 \\
\hline BRS-SC & 0.10 & 13.13 & $\underline{0.27}$ & 13.30 & -0.02 & 3.75 & 0.13 & 3.90 & 0.06 & 3.68 & $\underline{0.21}$ & 3.83 \\
\hline H09-14 & -0.16 & 12.87 & 0.11 & 13.13 & 0.05 & 3.83 & $\underline{0.21}$ & 3.99 & -0.16 & 3.47 & 0.07 & 3.69 \\
\hline FB200 & 0.37 & 13.40 & $\underline{0.38}$ & 13.41 & 0.01 & 3.79 & 0.15 & 3.92 & 0.22 & 3.84 & $\underline{0.26}$ & 3.88 \\
\hline BRS-GA & -0.35 & 12.68 & 0.00 & 13.03 & 0.29 & 4.07 & $\underline{0.36}$ & 4.14 & -0.37 & 3.25 & 0.00 & 3.62 \\
\hline BRS- Rubi & -0.18 & 12.85 & 0.08 & 13.11 & -0.32 & 3.45 & 0.00 & 3.78 & 0.25 & 3.87 & $\underline{0.28}$ & 3.90 \\
\hline Average $(\mu)$ & & & & 13.03 & & & & 3.78 & & & & 3.62 \\
\hline
\end{tabular}

g, genotypic effect; $\mu+\mathrm{g}$, average genotypic effect predicted in the environments; $\mu$, general experiment average. BRS Sol do Cerrado (BRS-SC); BRS Gigante Amarelo (BRS$\mathrm{GA})$. The five best hybrids for each evaluated trait are underlined. 
GP09-02, BRS Sol do Cerrado, with a new predicted average ranging from 3.93 to 3.83 (Table 3).

Significant differences at the levels of 1 and $5 \%$ were observed in the deviance analysis among genotypes for traits fruit length and diameter, peel thickness, peel mass, titratable acidity, SS/TA ratio, total cumulative productivity and pulp mass. Regarding the GxE interaction, only variables fruit length, percentage of pulp, soluble solids, titratable acidity, and SS/TA ratio, were not significant, which indicates low interaction effects for those traits (Table 4). This can also be observed by low values of $\sigma_{\text {int }}^{2}$ (Table 1). A study conducted with half-sibling passion fruit progenies evaluated in two environments in Rio de Janeiro also found no GxE interaction for the same traits (Oliveira et al. 2008).

The detailed study of the GxE interaction allows selecting the best genotypes for the various environmental conditions, and it results from the estimated phenotypic adaptability and stability (Silva et al. 2014), which enable identifying genotypes with behaviors that can be predicted according to environmental variations. For selection of the most stable and adaptable hybrid, it was the simultaneous selection method based on performance of genetic values (HMRPGV). Depending on the evaluated trait, the genotypes were classified differently through HMRPGV values (Table 4). However, in general considering all the studied traits, hybrids BRS Gigante Amarelo, HFOP-09, H09-09, GP09-02 and GP09-03, and BRS Sol do Cerrado stood out (Table 4). The most relevant traits for recommending the release of a hybrid are productivity, fruit mass, fruit length and diameter, and percentage of pulp. For the productivity trait, the most stable and adaptable in various environments were the hybrids BRS Gigante Amarelo, GP09-03, H09-09, BRS Sol do Cerrado, and H09-14. For fruit mass, the following genotypes were highlighted: BRS Gigante Amarelo, H09-30, HFOP-09, GP09-02, and H09-09. Fruits with larger lengths and/or diameters tend to have larger peel mass and thickness, which are not appreciated especially by the juice industry, because they negatively influence pulp mass and percentage of pulp (Negreiros et al. 2007, Freitas et al. 2011). However, hybrids BRS Gigante Amarelo, HFOP-09, H09-09, GP09-02, and BRS Sol do Cerrado were also found to have higher pulp mass, which indicates that this is not always a valid association (Table 4).

The chemical properties of fruits, such as soluble solids, titratable acidity and SS/TA ratio are important to the juice industry. Passion fruit pulp with higher sugar levels results in a smaller number of fruits required to obtain concentrated juice at $50^{\circ}$ Brix (Oliveira et al. 2008, Freitas et al. 2011). High acidity in the passion fruit juice is an important characteristic

Table 4. Deviance analysis and stability and adaptability (HMRPGV $x \mu$ ) in 14 yellow passion fruit hybrids evaluated in three locations in the State of Bahia for traits of fruits: total cumulative productivity (TCP), fruit mass (FM), fruit length (FL), fruit diameter (FD), peel thickness (PT), peel mass (PM), pulp mass (PUM), percentage of pulp (PP), soluble solids (SS), titratable acidity (TA), SS/TA ratio

\begin{tabular}{|c|c|c|c|c|c|c|c|c|c|c|c|}
\hline \multirow[b]{2}{*}{ Genotypes } & \multicolumn{11}{|c|}{ MHPRVG x Avarage $(\mu)$} \\
\hline & TCP & $\begin{array}{l}F M \\
(\mathrm{~g})\end{array}$ & $\begin{array}{c}\mathrm{FL} \\
(\mathrm{cm})\end{array}$ & $\begin{array}{c}\text { FD } \\
(\mathrm{mm})\end{array}$ & $\begin{array}{c}\text { PT } \\
(\mathrm{mm})\end{array}$ & $\begin{array}{l}\text { PM } \\
(\mathrm{g})\end{array}$ & $\begin{array}{l}\text { PUM } \\
\text { (g) }\end{array}$ & $\begin{array}{l}\text { PP } \\
(\%)\end{array}$ & $\begin{array}{c}\text { SS } \\
\text { (obrix) }\end{array}$ & $\begin{array}{c}\text { TA } \\
(\%)\end{array}$ & SS/TA \\
\hline GP09-03 & $\underline{29.44}$ & 223.74 & $\underline{10.21}$ & 8.37 & 6.68 & 121.79 & 67.56 & 29.02 & 13.03 & 3.81 & 3.55 \\
\hline HFOP-09 & 23.87 & $\underline{244.08}$ & $\underline{9.82}$ & $\underline{8.37}$ & $\underline{7.37}$ & $\underline{129.03}$ & $\underline{74.38}$ & 29.90 & $\underline{13.16}$ & $\underline{3.97}$ & 3.44 \\
\hline $\mathrm{H} 09-30$ & 20.43 & $\underline{246.34}$ & 9.15 & $\underline{9.12}$ & $\underline{8.06}$ & $\underline{138.67}$ & 68.93 & 28.15 & $\underline{13.55}$ & $\underline{4.27}$ & 3.37 \\
\hline BRS-SC & $\underline{28.38}$ & 223.74 & 9.24 & $\underline{8.54}$ & 6.54 & 115.76 & $\underline{70.29}$ & $\underline{30.49}$ & $\underline{13.16}$ & 3.74 & 3.69 \\
\hline H09-14 & $\underline{27.85}$ & 226.00 & 9.34 & $\underline{8.54}$ & $\underline{7.44}$ & $\underline{126.61}$ & 64.15 & 27.85 & 12.77 & $\underline{3.85}$ & 3.44 \\
\hline FB200 & 22.55 & 194.36 & 9.15 & 7.78 & 6.47 & 97.67 & 62.10 & $\underline{30.49}$ & $\underline{13.55}$ & 3.78 & $\underline{3.88}$ \\
\hline BRS-GA & $\underline{30.24}$ & $\underline{275.72}$ & $\underline{10.30}$ & $\underline{9.04}$ & 7.16 & $\underline{148.32}$ & $\underline{83.26}$ & 29.61 & 12.51 & $\underline{4.12}$ & 3.19 \\
\hline BRS- Rubi & 27.85 & 216.96 & 9.73 & 8.12 & $\underline{7.23}$ & $\underline{127.82}$ & 57.32 & 25.80 & 12.77 & 3.40 & $\underline{3.91}$ \\
\hline Average $(\mu)$ & 26,53 & 226,00 & 9,63 & 8,37 & 6,89 & 120,58 & 68,24 & 29,32 & 13,03 & 3,78 & 3,62 \\
\hline \multicolumn{12}{|c|}{ Deviance analysis } \\
\hline Genotypes & $614,23^{*}$ & 939,79 & $31,24 * *$ & $-14,98 * *$ & $121,24^{* *}$ & $826,93 * *$ & $742,45^{*}$ & 454,27 & 113,02 & $-64,96 * *$ & $-49,13 * *$ \\
\hline GxE & $618,00 *$ & $940,74 * *$ & 25,54 & $-16,19 * *$ & $117,00^{*}$ & $824,73 * *$ & $743,44^{*}$ & 453,37 & 112,37 & $-72,08$ & $-53,83$ \\
\hline
\end{tabular}

BRS Sol do Cerrado (BRS-SC); BRS Gigante Amarelo (BRS-GA). $\mu$, general experiment average. The five best hybrids for each evaluated trait are underlined. $* *$ and $*$ significant at $1 \%$ and $5 \%$, respectively. 
for the processing, due to the possibility of reducing the addition of acidifiers (Nascimento et al. 1999). The SS/TA ratio is considered one of the most practical ways to evaluate the flavor of fruits. Acidity is decisive for the SS/TA ratio, because high levels of acidity decrease the value of this ratio (Freitas et al. 2011). Inexpressive gains were observed for soluble solids, titratable acidity and SS/TA ratio, which explains the similarity between the genotypic values free of interaction $(\mu+\mathrm{g})$ and the new average. Besides that, the chemical characteristics were not significant for the GxE interaction (Table 4), so the genotypes presented similar behavior in the evaluated environments.

According to the results, the average heritability of the genotypes for the six evaluated traits in the three environments was found to have medium to high values, which also indicates the existence of enough variability for the selection of superior genotypes, even if they are hybrids in the last validation stage. There were GxE interactions for all traits except for fruit length, percentage of pulp, soluble solids, titratable acidity and SS/TA ratio. The hybrids that were the most stable and adaptable to the evaluated environments, and hence can be recommended for commercial planting in Bahia, are BRS Gigante Amarelo, BRS Sol do Cerrado, HFOP-09, H09-09, GP09-02 and GP09-03.

\section{ACKNOWLEDGEMENTS}

The authors would like to thank the Conselho Nacional de Desenvolvimento Científico e Tecnológico (CNPq) e Coordenação de Aperfeiçoamento de Pessoal de Nível Superior (CAPES) for the scholarships and the Fundação de Amparo à Pesquisa do Estado da Bahia (FAPESB: RED0004/2012) for the financial support and Bioenergia Orgânicos (Agreement FUNARBE 7697) for making experimental fields available.

\section{REFERENCES}

Atroch AL, Nascimento FJ and Resende MDV (2013) Seleção genética simultânea de progênies de guaranazeiro para produção, adaptabilidade e estabilidade temporal. Revista de Ciências Agrárias 56: 347-352.

Borges V, Ferreira PV, Soares L, Santos GM and Santos AMM (2010) Seleção de clones de batata-doce pelo procedimento REML/BLUP. Acta Scientiarum Agronomy 25: 643-649.

Brasil - Ministério da Agricultura e do Abastecimento (2003) Instrução Normativa № 12 de 4 de Setembro de 2003. Diário Oficial. Brasília, Seção1: 72-76.

Cargnelutti Filho A and Storck L (2009) Medidas do grau de precisão experimental em ensaios de competição de cultivares de milho. Pesquisa Agropecuária Brasileira 44: 111-117.

Carvalho AD, Fritsche Neto R and Geraldi IO (2008) Estimation and prediction of parameters and breeding values in soybean using REML/ BLUP and Least Squares. Crop Breeding and Applied Biotechnology 8: $230-235$.

Carvalho LP, Farias FJC, Morello CL and Teodoro PE (2016) Uso da metodologia REML/BLUP para seleção de genótipos de algodoeiro com maior adaptabilidade e estabilidade produtiva. Bragantia 75: 314-321.

Costa RB, Resende MDV, Gonçalves PS and Silva MA (2002) Individual multivariate REML/BLUP in the presence of genotype $x$ environment interaction in rubber tree (Hevea) breeding. Crop Breeding and Applied Biotechnology 2: 131-140.

Cruz CD, Regazzi AJ and Carneiro PCS (2004) Modelos Biométricos Aplicados ao Melhoramento Genético. $2^{\text {nd }}$ edn, Imprensa Universitária, Viçosa, 480p.
Farias Neto JT and Resende MDV (2001) Aplicação da metodologia de modelos mistos (REML/BLUP) na estimação de componentes de variância e predição de valores genéticos em pupunheira (Bactris gasipaes). Revista Brasileira Fruticultura 23: 320-324.

Freitas JPX, Oliveira EJ, Cruz Neto AJ and Santos LR (2011) Avaliação de recursos genéticos do maracujazeiro-amarelo. Pesquisa Agropecuária Brasileira 46: 1013-1020.

Gonçalves GM, Pio Viana A, Bezerra Neto, FV, Pereira MG and Pereira TNS (2007) Seleção e herdabilidade na predição de ganhos genéticos em maracujá-amarelo. Pesquisa Agropecuária Brasileira 42: 193-198.

Hallauer AR and Miranda Filho JB (1988) Quantitative genetics in maize breeding. lowa State University Press, Ames, 664p.

IBGE (2015) Banco de dados agregados: produção agrícola municipal. Sistema IBGE de Recuperação Automática - SIDRA. Available at <http://www.sidra.ibge.gov.br/>. Accessed on 06 Out, 2016.

Maia MCC, Resende MDV, Paiva JR, Cavalcanti JJV and Barros LMB (2009) Seleção simultânea para produção, adaptabilidade e estabilidade genotípicas em clones de cajueiro, via modelos mistos. Pesquisa Agropecuária Tropical 39: 43-50.

Medeiros SAF, Yamanishi OK, Peixoto JR, Pires MC, Junqueira NTV and Ribeiro JGBL (2009) Caracterização físico-química de progênies de maracujá-roxo e maracujá-azedo cultivados no Distrito Federal. Revista Brasileira Fruticultura 31: 492-499.

Moraes MC, Geraldi IO, Matta FP and Vieira MLC (2005) Genetic and phenotypic parameter estimates for yield and fruit quality traits from a single wide cross in yellow passion fruit. Hort Science $\mathbf{4 0}$ : 1978-1981.

Nascimento TB, Ramos JD and Menezes JB (1999) Características físicas do maracujá-amarelo produzido em diferentes épocas. Pesquisa 
Genetic parameters, adaptability and stability to selection of yellow passion fruit hybrids

Agropecuária Brasileira 34: 2353-2358.

Negreiros JRS, Araújo Neto SE, Álvares VS, Lima VA and Oliveira TK (2007) Caracterização de frutos de progênies de meios-irmãos de maracujazeiro-amarelo em Rio Branco - Acre. Revista Brasileira Fruticultura 30: 431-437.

Neves CG, Nunes OJ, Ledo CAS and Oliveira EJ (2013) Avaliação agronômica de parentais e híbridos de maracujazeiro- amarelo. Revista Brasileira Fruticultura 35: 191-198.

Oliveira EJ, Fraife Filho GA and Freitas JPX (2014) Desempenho produtivo e interação genótipo x ambiente em híbridos e linhagens de mamoeiro. Bioscience Journal 30: 402-410

Oliveira EJ, Santos VS, Lima, DS, Machado MD, Lucena RS, Motta TBN and Castellen MS (2008) Seleção em progênies de maracujazeiroamarelo com base em índices multivariados. Pesquisa Agropecuaria Brasileira 43: 1543-1549.

Pio Viana A, Silva FHL, Gonçalves GM, Silva MGM, Ferreira RT, Pereira TNS, Pereira MG, Amaral Júnior AT and Carvalho GF (2016) UENF Rio Dourado: a new passion fruit cultivar with high yield potential. Crop Breeding and Applied Biotechnology 16: 250-253.

Resende MDV and Dias LAS (2000) Aplicação da metodologia de modelos mistos (REML/BLUP) na estimação de parâmetros genéticos e predição de valores genéticos aditivos e genotípicos em espécies frutíferas. Revista Brasileira Fruticultura 22: 44-52.

Resende MDV (2004) Métodos estatísticos ótimos na análise de experimentos de campo. Embrapa Florestas, Brasília, 25p.
Resende MDV (2007) Software SELEGEM - REML/BLUP: sistema estatístico e seleção genética computadorizada via modelos lineares mistos. Embrapa Florestas, Brasília, 359p.

Resende MDV (2002) Genética biométrica e estatística no melhoramento de plantas perenes. Embrapa Informação Tecnológica, Brasília, 975p.

Resende MDV and Duarte JB (2007) Precisão e controle de qualidade em experimentos de avaliação de cultivares. Pesquisa Agropecuária Tropical 37: 182-194.

Rosado AM, Rosado TB, Alves AA, Laviola BG and Bhering LL (2012) Seleção simultânea de clones de eucalipto de acordo com produtividade, estabilidade e adaptabilidade. Pesquisa Agropecuária Brasileira 47: 964-971.

Santos EA, Viana AP, Freitas JCO, Rodrigues DL, Tavares RF, Paiva CL and Souza MM (2015) Genotype selection by REML/BLUP methodology in a segregating population from na interspecific Passiflora spp. crossing. Euphytica 208: 493-507.

Silva PR, Bisognin DA, Locatelli AB and Storck L (2014) Adaptability and stability of corn hybrids grown for high grain yield. Acta Scientiarum Agronomy 36: 175-181.

Silva FL, Barbosa MHP, Resende MDV, Peternelli LA and Pedrozo CA (2015) Efficiency of selection within sugarcane families via simulated individual BLUP. Crop Breeding and Applied Biotechnology 15: 1-9.

Viana AP, Pereira TNS, Pereira MG, Amaral Júnior AT, Souza MM and Maldonado JFM (2003) Parâmetros genéticos em populações de maracujazeiro-amarelo. Revista Ceres 51: 541-551. 